\title{
OS HOSPITAIS DAS UNIVERSIDADES PÚBLICAS BRASILEIRAS
}

São numerosas as atribuições e as razões explicativas da existência dos Hospitais Universitários (HUs). Emerge como principal a de serem destinados à formação de plêiade de alunos de Graduação em Medicina e para aperfeiçoamento de médicos em regime de residência médica ou matriculados em Cursos de Pós-Graduação "Lato ou Sensu Stricto".

Os graduandos em Medicina terão contato inicial com portadores de afecções somáticas e distúrbios anímicos. Aprenderão a identificar as moléstias e o linimento terapêutico existente, atual, para as diversas doenças. Aprenderão com os mestres que os portadores destas diversas afecções são pessoas com personalidade e sensibilidade próprias, merecedoras de todo respeito e carinho.

Os residentes e pós-graduandos terão oportunidade de aprofundamento em áreas específicas do conhecimento médico. De modo similar aprenderão a identificar as moléstias mais encontradiças e as modernas terapêuticas para cada afecção.

Os médicos vocacionados à carreira docente, e da pesquisa, encontrarão nestes hospitais campo para expansão dos conhecimentos, na área diagnóstica ou cura das doenças. Algumas unidades, com laboratórios experimentais, farão estudos em animais, estudos estes facultando avanços, por vezes marcantes, com aplicabilidade na espécie humana.

Presta-se também, nos HUs, medicina assistencial de elevado gabarito. Para estas unidades são drenados os atendimentos mais complexos. Perguntamo-nos: existe reconhecimento social e governamental por esta atuação, única e relevante, prestada por estes HUs?

Os HUs, na maioria, sobrevivem com o que arrecadam do SUS. Sabemos que a remuneração do SUS é muito baixa e não cobre as despesas de manutenção dos HUs.

Com os atendimentos prestados pelos HUs há resgate de enorme e obrigatória dívida dos diversos governos (Federal, Estadual, Municipal): prestação de assistência médica gratuita, universal e de qualidade para todos. Será isto verdade? Sabemos que o sonho é irreal.

É reduzida, contudo, a população que consegue atendimento nos HUs. A demanda pelos serviços é sempre crescente em face à realidade econômica do país. Estes procedimentos, como dito acima, são cercados de complexidade. A rede particular de hospitais (na totalidade conveniada com planos de saúde) ou não têm disponibilidade técnica, ou temerosas de não terem reembolso, simplesmente recusam os pacientes. É evidente que, em doenças graves, a permanência hospitalar é prolongada e não há lucro para as empresas prestadoras. Pelo contrário. Surgem então os HUs como redenção.

Não deveriam os diversos governos fornecer algum tipo de ressarcimento para estes HUs resgatando, ao menos parcialmente, a enorme divida social para com os mesmos? Não mereceriam algum tipo de recompensa com aquisição de equipamentos médicos e melhores instalações? Os prédios destes HUs são, no geral, muito antigos. Não deveria existir verba adequada e suficiente para manutenção destes edificios e do material nele existente?

A Diretoria 